\title{
Purification and characterization of RGA2, a Rho2 GTPase-activating protein from Tinospora cordifolia
}

\author{
Mohd. Amir ${ }^{1}$ Mohammad Aasif Dar ${ }^{1} \cdot$ Wahiduzzaman $^{1}$ • \\ Asimul Islam ${ }^{1}$. Faizan Ahmad ${ }^{1}$ - Md. Imtaiyaz Hassan ${ }^{1}$
}

Received: 13 August 2015/Accepted: 22 January 2016/Published online: 1 March 2016

(c) The Author(s) 2016. This article is published with open access at Springerlink.com

\begin{abstract}
Rho GTPases activating protein 2 (RGA2) is primarily involved in the modulation of numerous morphological events in eukaryotes. It protects plants by triggering the defense system which restricts the pathogen growth. This is the first report on the isolation, purification and characterization of RGA2 from the stems of Tinospora cordifolia, a medicinal plant. The RGA2 was purified using simple two-step process using DEAE-Hi-Trap FF and Superdex 200 chromatography columns, with a high yield. The purity of RGA2 was confirmed by SDS-PAGE and identified by MALDI-TOF/MS. The purified protein was further characterized for its secondary structural elements using the far-UV circular dichroism measurements. Our purification procedure is simple two-step process with high yield which can be further used to produce RGA2 for structural and functional studies.
\end{abstract}

Keywords Tinospora cordifolia - Chromatography · Protein purification - Rho GTPase activating protein . MALDI-TOF

\section{Introduction}

The Rho GTPases activating protein 2 (RGA2), belonging to the superfamily of small $\mathrm{G}$ proteins, is found in both higher and lower eukaryotic organisms. These proteins are

Electronic supplementary material The online version of this article (doi:10.1007/s13205-016-0400-3) contains supplementary material, which is available to authorized users.

Md. Imtaiyaz Hassan

mihassan@jmi.ac.in

1 Centre for Interdisciplinary Research in Basic Sciences, Jamia Millia Islamia, New Delhi 110025, India involved in diverse biological processes such as regulation of actin and microtubule cytoskeleton, cell cycle, vesicle trafficking, cell polarity, and gene expression (Bustelo et al. 2007; Cansado et al. 2010). Enzymatically it has GTPase activity which hydrolyzes the GTP to GDP and inorganic phosphate (Bourne et al. 1991). The activity of RGA2 is positively regulated by GDP-GTP exchange which catalyzes the exchange of GDP for GTP to activate the switch. However, GTPase-activating proteins stimulate the intrinsic GTPase activity to inactivate the switch and GDP dissociation inhibitors which block spontaneous activation, are considered as a negative regulators (Soto et al. 2010). These regulators are important for the specificity of Rho functions (Villar-Tajadura et al. 2008). These regulators actually modify the signaling activity of the GTPase (de Bettignies et al. 2001).

The plant-specific Rop subfamily of Rho GTPases is very similar to the mammalian Cdc42 and Rac GTPases (de Bettignies et al. 2001). These Rho GTPases play significant roles in the regulation of peroxide-mediated cell death, calciumdependent pollen tube growth, and other processes in plants (Roumanie et al. 2001; Wu et al. 2000). RGA2 is also found in higher plants where it acts as a small GTPase-associated defensome system for plant immunity (Liu et al. 2015). Furthermore, Rho GTPase activating proteins play important roles in the developmental process (Ye et al. 2014).

Tinospora cordifolia is a well-known Indian medicinal plant and its extract posses immunomodulatory and anticancer activities (Bala et al. 2015) especially against epithelial cancer cells (Maliyakkal et al. 2015). RGA2 has been reported to be purified and characterized from different sources. Yang and Watson (1993) reported that cloning, expression and characterization of rho, a ras-related small GTP-binding protein from the garden pea. Matsuda et al. (1996) have partially purified a membrane- 
associated GDP/GTP exchange proteins from the crude synaptic membrane fraction of rat brain using a combination of column chromatographies. RGA2 has been purified from $S$. pombe which was shown to regulates Rho2-Pck2 interaction and might participates in the regulation of the MAPK cell integrity pathway (Villar-Tajadura et al. 2008). Recently we have purified oligonucleotide binding (OB)fold protein (Amir et al. 2015a) and Ras-related protein, Rab5a (Amir et al. 2015b) from the stem of Tinospora cordifolia.

In this article we are for the first time reporting the purification and characterization of RGA2, a Rho2 GTPase activating proteins from Tinospora cordifolia. We used a simple chromatographic procedure to get this protein in plenty with high purity. We also performed structural analysis to establish a structure-function relationship.

\section{Materials and methods}

\section{Materials}

Tinospora cordifolia plant was obtained from Ch. Devi Lal Rudraksh Vatika Herbal Nature Park, Bhudkalan, Yamunanagar, Haryana, India. The bark of green stem was removed by scalpel blade and homogenized in $50 \mathrm{mM}$ Tris- $\mathrm{HCl} \mathrm{pH} 8.0$ with $500 \mathrm{mM} \mathrm{NaCl}$. All reagents of highest purity grade were purchased from Sigma-Aldrich (St. Louis, MO, USA), Merck (Darmstadt, Germany) and GE Healthcare. Hi Trap DEAE FF and Superdex-200 columns were purchased from GE Healthcare, Uppsala, Sweden. Electrophoresis reagents were purchased from the Bio-Rad Laboratories (Richmond, CA, USA). Databases used are http://www.matrixscience.com/, http://www. uniprot.org., http://blast.ncbi.nlm.nih.gov/Blast.cgi and http://cbdm-01.zdv.uni-mainz.de/ andrade/k2d2//.

\section{Protein isolation}

All purification steps were carried out at $4{ }^{\circ} \mathrm{C} .200 \mathrm{~g}$ of green stem of Tinospora cordifolia without bark was crushed with $50 \mathrm{mM}$ Tris- $\mathrm{HCl} \mathrm{pH} 8.0+500 \mathrm{mM} \mathrm{NaCl}$, and homogenized with blender in the ice-cold homogenization buffer ( $\mathrm{pH}$ 8.0) containing $1 \mathrm{mM}$ phenyl methyl sulphonyl fluoride (PMSF), $1 \mathrm{mM}$ dithiothreitol (DTT), $1 \mathrm{mM}$ ethylene diamine tetra acetate (EDTA), and $1 \%$ polyvinyl pyrrolidone (PVP), $4 \mathrm{ml}$ of buffer contained one gram of wet tissue. The homogenate was cleared by filtration through two layers of cheese cloth and left for overnight stirring at $4{ }^{\circ} \mathrm{C}$. Solid ammonium sulfate was added to the homogenate to achieve $30 \%$ saturation and kept for $12 \mathrm{~h}$. Ammonium sulfate precipitate was removed after centrifugation at $12000 \mathrm{~g}$ for $15 \mathrm{~min}$. The supernatant thus obtained was further saturated to $60 \%$ by ammonium sulfate and centrifuged at $12000 \mathrm{~g}$ for $15 \mathrm{~min}$. The supernatant obtained was further saturated to $90 \%$ ammonium sulfate and centrifuged at $12000 \mathrm{~g}$ for $15 \mathrm{~min}$. The ammonium sulfate precipitate thus obtained was collected and dissolved in $50 \mathrm{mM}$ Tris- $\mathrm{HCl}$ buffer, $\mathrm{pH} 8.0$ and was extensively dialyzed against the same buffer.

\section{Ion-exchange chromatography}

The dialyzed sample was loaded on Hi Trap DEAE FF $(1 \mathrm{ml}, 7 \times 25 \mathrm{~mm})$ column (GE Healthcare), pre-equilibrated with $50 \mathrm{mM}$ Tris- $\mathrm{HCl}$ buffer, $\mathrm{pH}$ 8.0. Akta purifier (GE Healthcare) connected system to control the flow rate and fraction size of elution. The sample was injected into the column with $5 \mathrm{ml}$ loop. The flow rate of $1 \mathrm{ml} / \mathrm{min}$ is maintained for both binding and elution. The column was washed with equilibration buffer, and the bound proteins were eluted with $\mathrm{NaCl}$ linear gradient $(0-1 \mathrm{M} \mathrm{NaCl}$ w/v) in the same buffer. The first peak obtained at $0.10 \mathrm{M}$ of $\mathrm{NaCl}$ was pooled, concentrated using Amicon Ultra $3 \mathrm{~K}$ device (Merck Darmstadt, Germany).

\section{Gel filtration chromatography}

Concentrated protein sample $(1 \mathrm{ml})$ was injected on to the Superdex 200 column connected to the Akta purifier (GE Healthcare, USA). The column was equilibrated with $50 \mathrm{mM}$ Tris-HCl buffer, $\mathrm{pH} 8.0$ at the rate of $0.5 \mathrm{ml} / \mathrm{min}$. The elution profile was analyzed by unicorn manager (version 5.0) for the absorbance at $280 \mathrm{~nm}$ against elution volume (ml).

\section{Gel electrophoresis}

Molecular mass of the protein was determined by SDSPAGE as described by Laemmli (Laemmli 1970). The SDS-PAGE was performed in a slab gel assembly using $12 \%(\mathrm{w} / \mathrm{v})$ acrylamide and $0.02 \%(\mathrm{w} / \mathrm{v})$ bisacrylamide in the separating gel and $5 \%(\mathrm{w} / \mathrm{v})$ acrylamide and $0.16 \%$ $(\mathrm{w} / \mathrm{v})$ bisacrylamide in the stacking gel. The gel buffer was $0.375 \mathrm{M}$ Tris- $\mathrm{HCl}, \mathrm{pH}$ 8.8. The electrode buffer was $25 \mathrm{mM}$ Tris-HCl, pH 8.3 containing $0.192 \mathrm{M}$ glycine. Gels were stained with coomassie brilliant blue G-250. Molecular mass standards (10-180 kDa) were used for the molecular mass determination.

\section{Mass spectrometry}

The band of RGA2 was excised from the SDS-PAGE and subjected for identification to the matrix-assisted laser desorption/ionization time of flight (MALDI-TOF) (Kratos analytical, shimadzu group company, japan) equipped with 
a $337 \mathrm{~nm}$ pulsed UV laser, a $1.7 \mathrm{~m}$ length flight tube and a curved field reflectron. A detail of MALDI-TOF procedure was described elsewhere (Dar et al. 2014; Hassan et al. $2007,2008 b)$. The observed mass spectra, peak areas versus mass/electric charge $(\mathrm{m} / \mathrm{z})$ of mono-isotopic ions were calculated with MASCOT distiller software version1.1.2.0 (Matrix Science, London, UK).

\section{Circular dichroism measurements}

Circular Dichroism (CD) spectra were measured in Jasco Spectropolarimeter (Model J-1500) equipped with peltiertype temperature controller (CDF-426S). The far-UV CD spectra (250-200 nm) were recorded at $25 \pm 0.1{ }^{\circ} \mathrm{C}$ using a $1 \mathrm{~mm}$ path length cell, and the protein concentration used was $0.28 \mathrm{mg} / \mathrm{ml}$. The samples were prepared in $50 \mathrm{mM}$ Tris- $\mathrm{HCl}$ buffer at $\mathrm{pH}$ 8.0. The raw $\mathrm{CD}$ data were converted to protein concentration independent parameter, the mean residue ellipticity, $(\theta)_{\lambda}\left(\operatorname{deg} \mathrm{cm}^{2} \mathrm{dmol}^{-1}\right)$ using the relation, $[\theta]_{\lambda}=M_{o} \theta_{\lambda} / 10 l c$ where $\theta_{\lambda}$ is the observed ellipticity in millidegrees, $M_{\mathrm{o}}$ is the mean residue weight of the protein, $c$ is concentration in $\mathrm{mg} \mathrm{ml}^{-1}$, and $l$ is the path length of the cell in $\mathrm{cm}$.

\section{Results and discussion}

The root, stem, and leaves of Tinospora cordifolia are used in Ayurvedic medicine (Upadhyay et al. 2010). Phytochemicals present in the Tinospora cordifolia are used for the treatment of diabetes, high cholesterol, gout, allergic rhinitis, lymphoma and other cancers, upset stomach, rheumatoid arthritis, hepatitis, gonorrhea, syphilis, peptic ulcer disease, fever, and to boost the immune system (Saha and Ghosh 2012). Apart from several phytochemicals, this plant contains large number of proteins which has medicinal impact. Among these proteins, RGA2 is also one of the important protein, and having many clinical significance such as oocyte maturation, fertilization and early embryo development (Balakier et al. 2002). Structurally, RGA2 protein contains leucine-rich repeat (LRR) domains which are involved in diverse biological processes including signal transduction, cell adhesion and the innate immune response. Here, we report a rapid method for purification of RGA2 from Tinospora cordifolia for the first time followed by its structural characterization.

\section{Purification of RGA2}

A summary of a typical purification procedure is given in Table 1. The dialyzed protein precipitated by $90 \%$ ammonium sulfate was subjected to weak anion-exchange chromatography on Hi Trap DEAE FF. Bound proteins were eluted with a linear gradient of $\mathrm{NaCl}$. We observed four peaks in the chromatogram of the weak anion-exchange elution (Fig. 1). The first peak, eluted at $0.10 \mathrm{M}$ $\mathrm{NaCl}$ showing three prominent bands at 50, 35 and $20 \mathrm{kDa}$ along with some low molecular mass impurities on SDSPAGE. The concentrated pool of partially purified RGA2 protein from Hi Trap DEAE FF column was loaded on the Superdex 200 column, pre-equilibrated with $50 \mathrm{mM}$ Tris buffer ( $\mathrm{pH}$ 8.0). Proteins were eluted with the same buffer at a flow rate of $0.5 \mathrm{ml} / \mathrm{min}$. Fractions of $2.0 \mathrm{ml}$ were collected and monitored for absorbance at $280 \mathrm{~nm}$ (Fig. 2). Fractions showing high absorbance at $280 \mathrm{~nm}$ were pooled and concentrated for further analysis. The second peak showed a single band at $35 \mathrm{kDa}$ (Fig. 3).

\section{Protein identification}

The single band shown in Fig. 3 was excised from the gel. This band after trypsinization was subjected to mass spectrometry. 13 fragments of different size were obtained after trypsinazation. Molecular mass and sequence of each fragments are shown in Table 2. These fragments were used for the identification of purified protein using mascot search program. A significant mascot score clearly indicates that the purified protein is RGA2 with sequence coverage of $35 \%$. Since, the sequence of RGA2 is not genbank therefore we considered RGA2 sequence of Triticum aestivum with GenBank: ACO55039.1 to identify the purified protein as RGA2. The purified RGA2 was freeze dried and stored for further uses.

\section{Secondary structure measurement}

Secondary structure measurement of protein using CD provided information that whether the purified protein is folded, and to checks its conformation or stability (Alam Khan et al. 2009, 2010; Greenfield 2006; Rehman et al. 2011; Singh et al. 2015). In addition, analysis of CD spectra helps to estimate the secondary structure composition of a protein (Anwer et al. 2014, 2015; Haque et al. 2015; Khan et al. 2016; Rahaman et al. 2015). Prediction of secondary structure for the CD data measured to $178 \mathrm{~nm}$ for $\alpha$-helix: 0.97 for $\beta$-sheet: 0.75 for $\beta$-turn: 0.50 and for other structures: 0.89 (Manavalan and Johnson 1987). Structure analyses will also provide an insight into the function of protein (Hassan et al. 2008a, 2010, 2012, 2013). Hence, we performed CD measurements to estimate the secondary structure of purified RGA2.

The far-UV CD spectrum provided information about secondary structure of RGA2 (Fig. 4). A deep peak at the $222 \mathrm{~nm}$ is indication of $\alpha$-helix in the protein structure. 
Table 1 Purification summary of RGA2

\begin{tabular}{|c|c|c|c|c|c|}
\hline S.No. & Purification step & Volume (ml) & Protein $(\mathrm{mg} / \mathrm{ml})^{\mathrm{b}}$ & Total protein (mg) & Yield $(100 \%)$ \\
\hline 1 & Crude extract ${ }^{\mathrm{a}}$ & 880.0 & 1.8 & 1584 & 100 \\
\hline 2 & Ammonium sulfate (90\% cut) & 50 & 1.6 & 80 & 5.05 \\
\hline 3 & DEAE column (pooled peak) & 55 & 1.3 & 71 & 4.51 \\
\hline 4 & Superdex 200 column (pooled peak) & 20 & 1 & 20 & 1.26 \\
\hline
\end{tabular}

${ }^{\text {a }}$ From $200 \mathrm{~g}$ of wet weight of $T$. cordifolia stem

b Protein concentration determined by Lowry assay using BSA as a standard protein

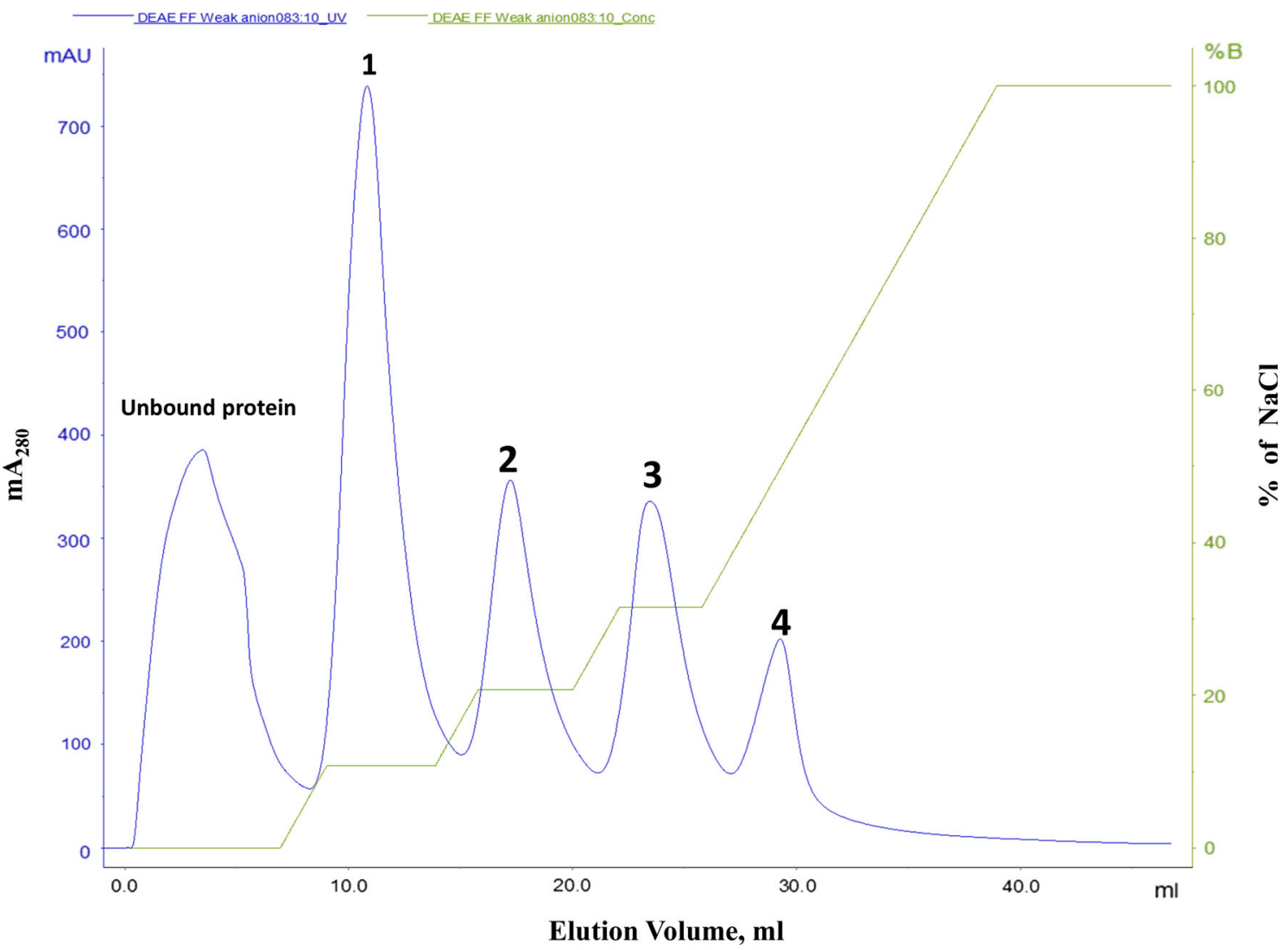

Fig. 1 Elution profile [plot of mA280 (milli absorbance at $280 \mathrm{~nm}$ ) versus elution volume $(\mathrm{ml})$ ] of weak anion exchanger Hi Trap DEAE FF. The second curve represents the gradient of $\mathrm{NaCl}(0-100 \%$ of $\mathrm{B})$

This far-UV CD spectrum was analyzed to determine secondary structure content, we used K2D2 server (PerezIratxeta and Andrade-Navarro 2008). The secondary structure convoluted from the spectrum was found to be $18 \%$ of $\alpha$-helix, $32 \% \beta$-Sheet and $50 \%$ are of random coil. We also determined $\alpha$-helical content of the protein using CD value at $222 \mathrm{~nm}$ (Correa and Ramos 2009) to confirm our data obtained by K2D2. We used the procedure given by Morrisett et al. (1973) to determine the amount of $\alpha$-helix in our protein which came out to be $16 \%$ which is where buffer $\mathrm{A}$ is $10 \mathrm{mM}$ Tris- $\mathrm{HCl}(\mathrm{pH} 8.0)$ and $\mathrm{B}$ is $1.0 \mathrm{M} \mathrm{NaCl}$ in the same buffer

in good agreement with that obtained by K2D2. Thus these results confirmed that our protein has a significant amount of $\beta$-Sheet with $\alpha$-helical content and random coil in different proportion. The crystal structure of RGA2 has not been determined so far. However, we tried to model the RGA2 using the sequence (GenBank: ACO55039.1) and observed a considerable agreement with the structure predicted through $\mathrm{CD}$.

To check the stability of RGA2, we have measured the $\mathrm{CD}$ spectrum at $85{ }^{\circ} \mathrm{C}$ and found a significant decrease in 


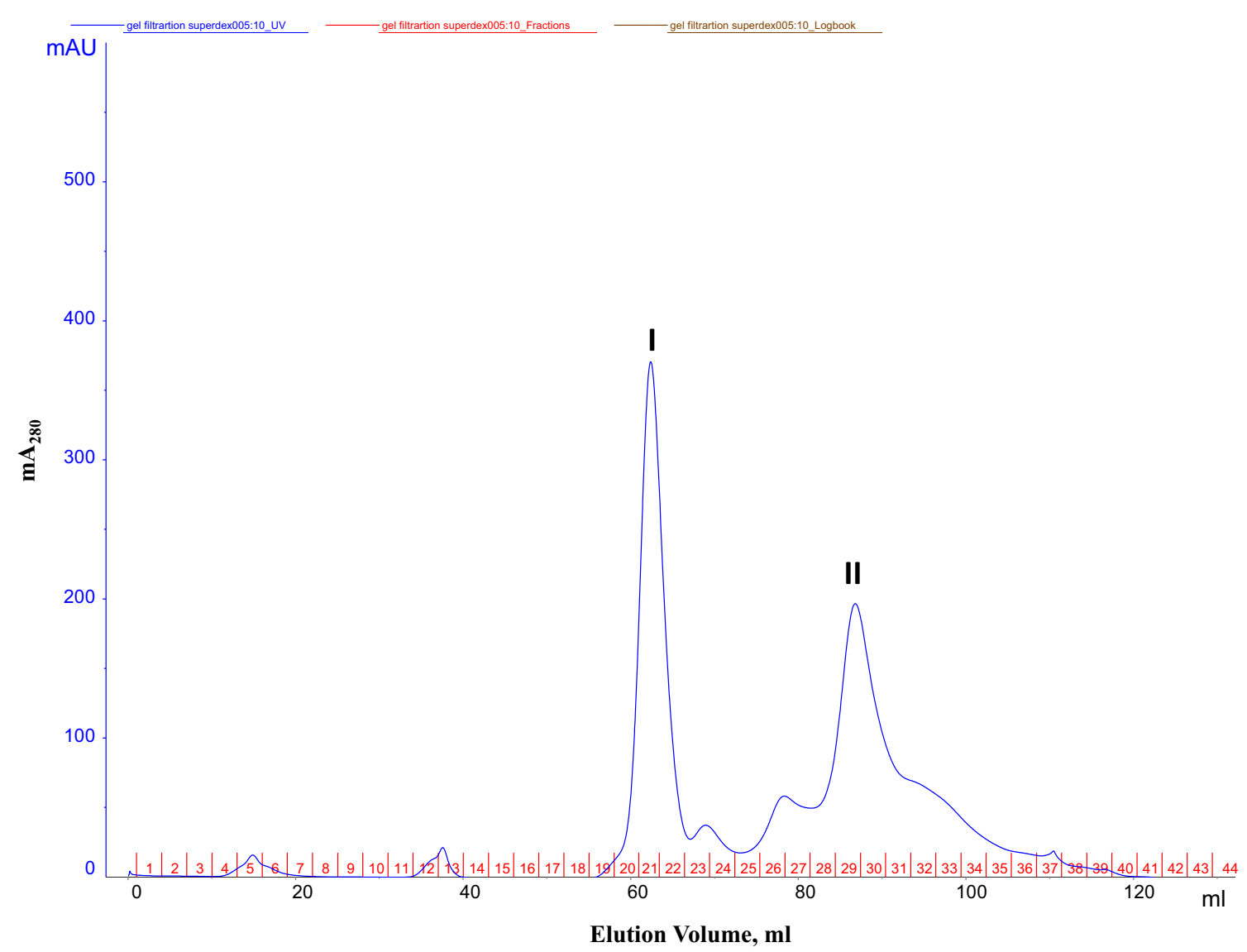

Fig. 2 Elution profile of gel filtration superdex 200 column. The peaks were obtained as a function of $\mathrm{X}$ as elution volume in ml and $Y$ axis is $\mathrm{mA}$ at $280 \mathrm{~nm}$

Fig. 3 SDS-PAGE of peaks obtained during weak anion exchange and Gel filtration chromatography. Lane I is protein marker (10-180 kDa), Lane II is loading sample, Lane III is $\mathrm{Pk} 1$ of DEAE

chromatogram and Lanes IV and V are PK II of gel filtration superdex 200 chromatogram

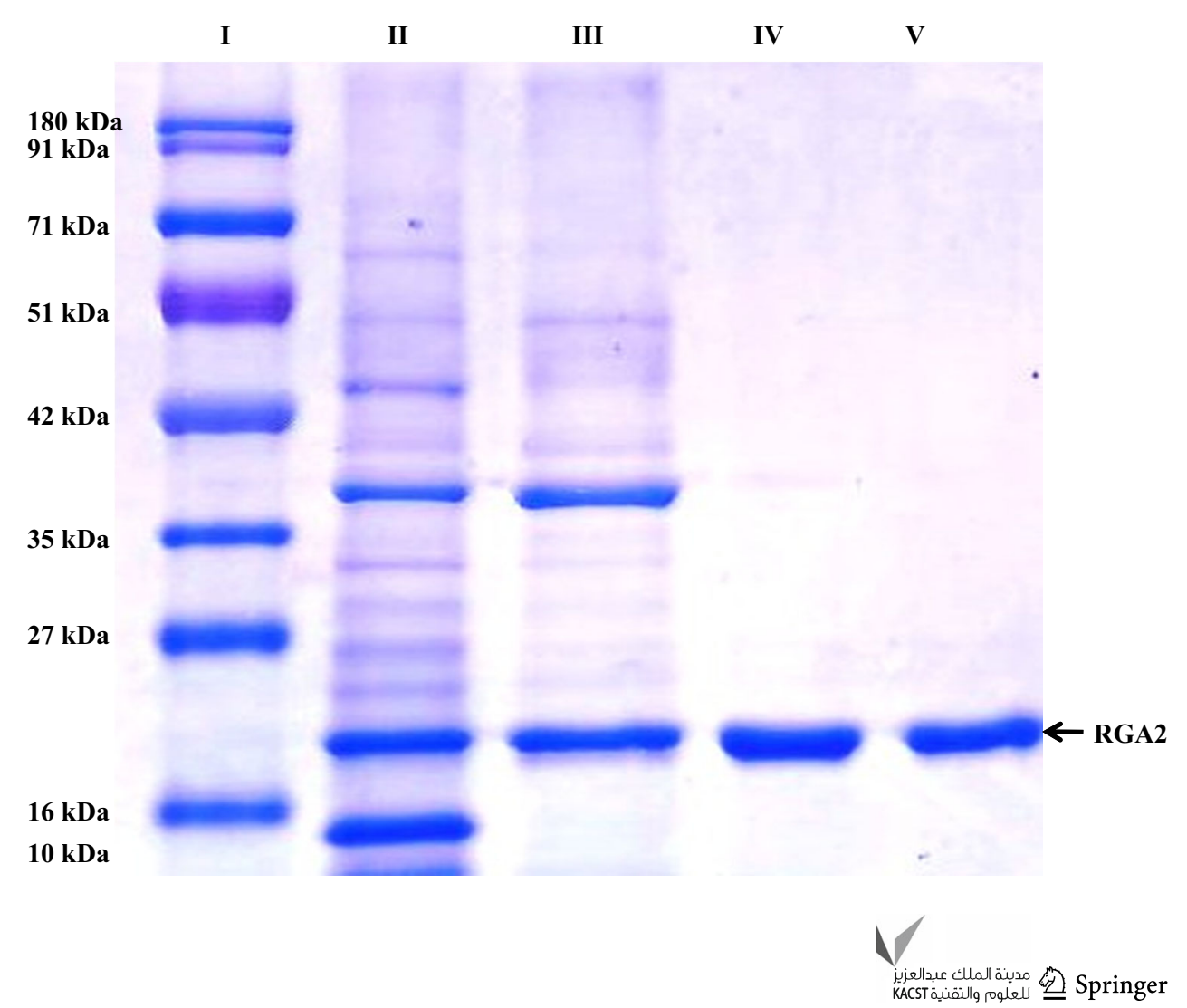


Table 2 List of peptide fragments obtained after trypsinization

\begin{tabular}{llll}
\hline S. No. & Mass Mr. & Range & P sequence \\
\hline 1 & $973-5080$ & $178-185$ & QLDTLDIR \\
2 & $1401-7517$ & $1-12$ & RWIAEGYPGVVR \\
3 & $1415-7442$ & $293-305$ & LGVMGINEKNDVK \\
4 & $1617-8991$ & $199-212$ & LQKLQHLHAGFPTK \\
5 & $1645-8709$ & $57-71$ & EIGISKSMEGNLVLR \\
6 & $2112-0687$ & $202-219$ & LQHLHAGFPTKGNYLCTR \\
7 & $2118-9779$ & $13-30$ & NKSTEEVAESYFMDLISR \\
8 & $2203-1136$ & $111-128$ & SITVFGEWKPFFLSDKMR \\
9 & $2371-3032$ & $178-198$ & QLDTLDIRGTSIVMLPQTIIK \\
10 & $2371-3032$ & $178-198$ & QLDTLDIRGTSIVMLPQTIIK \\
11 & $2391-2659$ & $265-286$ & SLHTIRGVHVAYGDAVIQEIGR \\
12 & $2821-3150$ & $15-38$ & STEEVAESYFMDLISRSMLLPSQR \\
13 & $2821-3150$ & $15-38$ & STEEVAESYFMDLISRSMLLPSQR \\
\hline
\end{tabular}

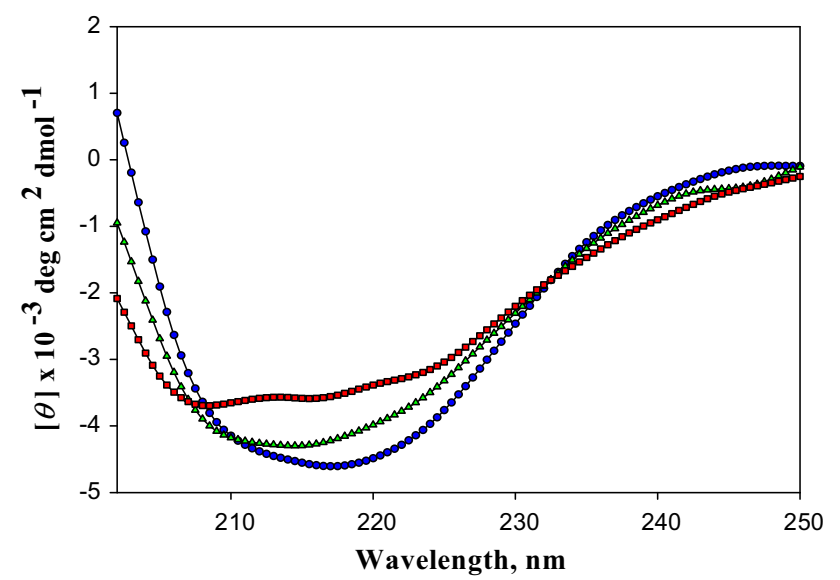

Fig. 4 Far-UV CD spectrum of RGA2 at different temperatures in $50 \mathrm{mM}$ Tris-HCl buffer $\mathrm{pH}$ 8.0. Far-UV CD spectrum at $25^{\circ} \mathrm{C}$, at $85{ }^{\circ} \mathrm{C}$ and at $25^{\circ} \mathrm{C}$ after cooling is shown in blue, red and green, respectively

the peak intensity at $222 \mathrm{~nm}$ (Fig. 4). However, it is interesting to note that this protein is not completely denatured even at $85{ }^{\circ} \mathrm{C}$. We further checked that do such heat-induced denaturation is reversible or not? After cooling the protein from 85 to $25^{\circ} \mathrm{C}$ we further measured the far-UV CD spectrum and found a significant gain in the secondary structure after cooling. These observations clearly indicate a reversible nature of RGA2 during heatinduced denaturation.

\section{Conclusions}

Here, for the first time we are reporting a simplified procedure for the purification of RGA2 from green stems of Tinospora cordifolia. We have fractionated proteins of RGA2 of green stems of plants using ammonium sulfate and precipitate obtained at $90 \%$ of ammonium sulfate was applied to DEAE-Hi-Trap FF and superdex 200 columns. The purified protein was subjected to MALDI-TOF for identification. We produced a significant amount of RGA2 from Tinospora cordifolia by twostep purification procedure. The method developed in our laboratory results in high yield and purity of RGA2 which may be used for further structural and biochemical studies. Tinospora cordifolia has an importance in traditional Ayurvedic medicine used for ages in the treatment and hence, studies on RGA2 will further strengthen our understanding for the medicinal significance of this plant.

Acknowledgments We thank Ch. Devi Lal Rudraksh Vatika Herbal Nature Park, Bhudkalan, Yamunanagar, Haryana for providing plant. MA thanks the University Grants Commission for the award of fellowship. FA and MIH thank to the CSIR and DST for the financial support. Wahiduzzaman and MAD sincerely thank Indian Council of Medical Research for the Senior Research fellowship. Authors sincerely thank to the Department of Science and Technology, Government of India for the FIST support (FIST program No. SR/ FST/LSI-541/2012).

\section{Compliance with ethical standards}

Conflict of interest The authors have no substantial financial or commercial conflicts of interest with the current work or its publication.

Open Access This article is distributed under the terms of the Creative Commons Attribution 4.0 International License (http:// creativecommons.org/licenses/by/4.0/), which permits unrestricted use, distribution, and reproduction in any medium, provided you give appropriate credit to the original author(s) and the source, provide a link to the Creative Commons license, and indicate if changes were made. 


\section{References}

Alam Khan MK, Das U, Rahaman MH, Hassan MI, Srinivasan A, Singh TP, Ahmad F (2009) A single mutation induces molten globule formation and a drastic destabilization of wild-type cytochrome $\mathrm{c}$ at $\mathrm{pH}$ 6.0. J Biol Inorg Chem 14:751-760

Alam Khan MK, Rahaman MH, Hassan MI, Singh TP, MoosaviMovahedi AA, Ahmad F (2010) Conformational and thermodynamic characterization of the premolten globule state occurring during unfolding of the molten globule state of cytochrome c. J Biol Inorg Chem 15:1319-1329

Amir M, Haque MA, Wahiduzzaman, Dar MA, Islam A, Ahmad F, Hassan MI (2015a) Purification and characterization of oligonucleotide binding (OB)-fold protein from medicinal plant $T i$ nospora cordifolia. J Chromatogr B Anal Technol Biomed Life Sci 1008:38-44

Amir M, Wahiduzzaman, Dar MA, Haque MA, Islam A, Ahmad F, Hassan MI (2015b) Purification and characterization of Ras related protein, Rab5a from Tinospora cordifolia. Int J Biol Macromol 82:471-479

Anwer K, Parmar A, Rahman S, Kaushal A, Madamwar D, Islam A, Hassan MI, Ahmad F (2014) Folding and stability studies on $\mathrm{C}$-PE and its natural N-terminal truncant. Arch Biochem Biophys 545:9-21

Anwer K, Sonani R, Madamwar D, Singh P, Khan F, Bisetty K, Ahmad F, Hassan MI (2015) Role of N-terminal residues on folding and stability of C-phycoerythrin: simulation and ureainduced denaturation studies. J Biomol Struct Dyn 33:121-133

Bala M, Pratap K, Verma PK, Singh B, Padwad Y (2015) Validation of ethnomedicinal potential of Tinospora cordifolia for anticancer and immunomodulatory activities and quantification of bioactive molecules by HPTLC. J Ethnopharmacol 175:131-137

Balakier H, Dziak E, Sojecki A, Librach C, Michalak M, Opas M (2002) Calcium-binding proteins and calcium-release channels in human maturing oocytes, pronuclear zygotes and early preimplantation embryos. Hum Reprod 17:2938-2947

Bourne HR, Sanders DA, McCormick F (1991) The GTPase superfamily: conserved structure and molecular mechanism. Nature 349:117-127

Bustelo XR, Sauzeau V, Berenjeno IM (2007) GTP-binding proteins of the Rho/Rac family: regulation, effectors and functions in vivo. BioEssays 29:356-370

Cansado J, Soto T, Gacto M, Perez P (2010) Rga4, a Rho-GAP from fission yeast: finding specificity within promiscuity. Commun Integr Biol 3:436-439

Correa DHA, Ramos CHI (2009) The use of circular dichroism spectroscopy to study protein folding, form and function. Afr J Biochem Res 3:164-173

Dar MA, Wahiduzzaman, Islam A, Hassan MI, Ahmad F (2014) Purification and characterization of calreticulin: a $\mathrm{Ca}(2)(+)-$ binding chaperone from sheep kidney. Appl Biochem Biotechnol. 174:1771-1783

de Bettignies G, Thoraval D, Morel C, Peypouquet MF, Crouzet M (2001) Overactivation of the protein kinase C-signaling pathway suppresses the defects of cells lacking the Rho3/Rho4-GAP Rgd1p in Saccharomyces cerevisiae. Genetics 159:1435-1448

Greenfield NJ (2006) Using circular dichroism spectra to estimate protein secondary structure. Nat Protoc 1:2876-2890

Haque MA, Zaidi S, Ubaid-Ullah S, Prakash A, Hassan MI, Islam A, Batra JK, Ahmad F (2015) In vitro and in silico studies of ureainduced denaturation of yeast iso-1-cytochrome $\mathrm{c}$ and its deletants at $\mathrm{pH} 6.0$ and $25^{\circ} \mathrm{C}$. J Biomol Struct Dyn 33:1493-1502

Hassan MI, Kumar V, Kashav T, Alam N, Singh TP, Yadav S (2007) Proteomic approach for purification of seminal plasma proteins involved in tumor proliferation. J Sep Sci 30:1979-1988
Hassan MI, Bilgrami S, Kumar V, Singh N, Yadav S, Kaur P, Singh TP (2008a) Crystal structure of the novel complex formed between zinc alpha2-glycoprotein (ZAG) and prolactin-inducible protein (PIP) from human seminal plasma. J Mol Biol 384:663-672

Hassan MI, Kumar V, Singh TP, Yadav S (2008b) Purification and characterization of zinc alpha2-glycoprotein-prolactin inducible protein complex from human seminal plasma. J Sep Sci $31: 2318-2324$

Hassan MI, Toor A, Ahmad F (2010) Progastriscin: structure, function, and its role in tumor progression. $\mathrm{J}$ Mol Cell Biol 2:118-127

Hassan MI, Saxena A, Ahmad F (2012) Structure and function of von Willebrand factor. Blood Coagul Fibrinolysis 23:11-22

Hassan MI, Waheed A, Grubb JH, Klei HE, Korolev S, Sly WS (2013) High resolution crystal structure of human beta-glucuronidase reveals structural basis of lysosome targeting. PLoS One 8:e79687

Khan P, Parkash A, Islam A, Ahmad F, Hassan MI (2016) Molecular basis of the structural stability of hemochromatosis factor E: a combined molecular dynamic simulation and GdmCl-induced denaturation study. Biopolymers 105:133-142. doi:10.1002/bip. 22760

Laemmli UK (1970) Cleavage of structural proteins during the assembly of the head of bacteriophage T4. Nature 227:680-685

Liu J, Park CH, He F, Nagano M, Wang M, Bellizzi M, Zhang K, Zeng X, Liu W, Ning Y, Kawano Y, Wang GL (2015) The RhoGAP SPIN6 associates with SPL11 and OsRac1 and negatively regulates programmed cell death and innate immunity in rice. PLoS Pathog 11:e1004629

Maliyakkal N, Appadath Beeran A, Balaji SA, Udupa N, Ranganath Pai S, Rangarajan A (2015) Effects of Withania somnifera and Tinospora cordifolia extracts on the side population phenotype of human epithelial cancer cells: toward targeting multidrug resistance in cancer. Integr Cancer Ther 14:156-171

Manavalan P, Johnson WC Jr (1987) Variable selection method improves the prediction of protein secondary structure from circular dichroism spectra. Anal Biochem 167:76-85

Matsuda S, Nakanishi H, Sasaki T, Takai Y (1996) A membraneassociated GDP/GTP exchange protein specific for Rho small GTP-binding protein-partial purification and characterization from rat brain. Oncogene 12:915-920

Morrisett JD, David JS, Pownall HJ, Gotto AM Jr (1973) Interaction of an apolipoprotein (apoLP-alanine) with phosphatidylcholine. Biochemistry 12:1290-1299

Perez-Iratxeta C, Andrade-Navarro MA (2008) K2D2: estimation of protein secondary structure from circular dichroism spectra. BMC Struct Biol 8:25

Rahaman H, Alam Khan MK, Hassan MI, Islam A, MoosaviMovahedi AA, Ahmad F (2015) Heterogeneity of equilibrium molten globule state of cytochrome $\mathrm{c}$ induced by weak salt denaturants under physiological condition. PLoS One 10:e0120465

Rehman MT, Dey P, Hassan MI, Ahmad F, Batra JK (2011) Functional role of glutamine 28 and arginine 39 in double stranded RNA cleavage by human pancreatic ribonuclease. PLoS One 6:e17159

Roumanie O, Weinachter C, Larrieu I, Crouzet M, Doignon F (2001) Functional characterization of the Bag7, Lrg1 and Rgd2 RhoGAP proteins from Saccharomyces cerevisiae. FEBS Lett 506:149-156

Saha S, Ghosh S (2012) Tinospora cordifolia: one plant, many roles. Anc Sci Life 31:151-159

Singh R, Hassan MI, Islam A, Ahmad F (2015) Cooperative unfolding of residual structure in heat denatured proteins by urea and guanidinium chloride. PLoS One 10:e128740 
Soto T, Villar-Tajadura MA, Madrid M, Vicente J, Gacto M, Perez P, Cansado J (2010) Rga4 modulates the activity of the fission yeast cell integrity MAPK pathway by acting as a Rho2 GTPaseactivating protein. J Biol Chem 285:11516-11525

Upadhyay AK, Kumar K, Kumar A, Mishra HS (2010) Tinospora cordifolia (Willd.) Hook. f. and Thoms. (Guduchi)—validation of the ayurvedic pharmacology through experimental and clinical studies. Int J Ayurveda Res 1:112-121

Villar-Tajadura MA, Coll PM, Madrid M, Cansado J, Santos B, Perez $\mathrm{P}$ (2008) Rga2 is a Rho2 GAP that regulates morphogenesis and cell integrity in S. pombe. Mol Microbiol 70:867-881
Wu G, Li H, Yang Z (2000) Arabidopsis RopGAPs are a novel family of rho GTPase-activating proteins that require the Cdc42/Racinteractive binding motif for rop-specific GTPase stimulation. Plant Physiol 124:1625-1636

Yang Z, Watson JC (1993) Molecular cloning and characterization of rho, a ras-related small GTP-binding protein from the garden pea. Proc Natl Acad Sci USA 90:8732-8736

Ye W, Chen X, Zhong Z, Chen M, Shi L, Zheng H, Lin Y, Zhang D, Lu G, Li G, Chen J, Wang Z (2014) Putative RhoGAP proteins orchestrate vegetative growth, conidiogenesis and pathogenicity of the rice blast fungus Magnaporthe oryzae. Fungal Genet Biol 67:37-50 